УДК 930.2:[37:001.891

DOI: https://doi.org/

\title{
ОЛЕНА ІЛЬЧЕНКО
}

ORCID http://orcid.org/ 0000-0003-4869-274X

(Полтава)

Work place: Poltava V. G. Korolenko National Pedagogical University

Country: Ukraine

Email: ilchenko.olena@gmail.com

\section{БІОГРАФІЧНИЙ МЕТОД В ІСТОРИКО-ПЕДАГОГІЧНОМУ ДОСЛІДЖЕННІ: СУТНІСТЬ, ПРИНЦИП, СПЕЦИФІКА}

\begin{abstract}
У статті проаналізовано роль і значення біографічного методу як провідного інструменту вивчення творчої біографії особистості в історії педагогіки. Зазначено, що, як науковий метод осягнення індивідуальності, біографічний метод набуває все більшої популярності, поширюючи дослідницький потенціал на всю систему гуманітарного знання, - філософію, історію, соціологію, психологію, історію педагогіки та ін. науки. Узагальнено особливості біографічного методу в історико-педагогічному дослідженні, проаналізовано сукупність наукових принципів пізнання, які забезпечують його ефективну реалізацію (принцип історизму, системності, наукової об’єктивності, відсутності догматизму, опори на історичні джерела).

Автором зазначено, що, незважаючи на зростання кількісного масиву історико-педагогічних біографічних розвідок, залишається важливою їх якість і прогресивність для науки, що може бути зреалізовано через: а) пріоритет вивчення генезису і трансформування феноменів науки, адекватний пошук у минулому витоків сучасних проблем; б) методологічно грамотне застосування біографічного методу з усією сукупністю його ідей і принципів, правил і прийомів; в) дотримання органічної єдності трьох проекцій - «ретроспективного осмислення минулого, об'єктивної оцінки сучасного, чіткого й усвідомленого прогнозування майбутнього»; г) розкриття істинного історико-педагогічного процесу 3 усіма його хибами і недоліками, з аналізом досягнень і помилок персоналій; д) володіння дослідником високою науковою кваліфікацією, педагогічним світоглядом, широкою ерудицією та етикою, досвідом критичного аналізу джерел, знанням закономірностей перебігу історико-педагогічного процесу тощо.
\end{abstract}

Ключові слова: педагогічна персоналія; біографічний метод біографія; принципи пізнання; специфіка біографічного методу; історико-педагогічне дослідження.

Постановка проблеми в загальному вигляді. «Історія науки має критично складатися кожним науковим поколінням, і не тільки тому, що змінюються запаси наших знань про минуле, відкриваються нові прийоми відновлення колишнього. Ні! Необхідно знов науково переробляти історію науки, знов уходити в минуле, оскільки завдяки розвитку сучасного знання у минулому одержує значення одне і втрачає інше. Кожне покоління наукових дослідників знаходить в історії науки відбиття наукових течій свого часу. Рухаючись уперед, наука не лише створює нове, але і неминуче переоцінює старе, пережите» (Вернадский, 1922, с. 112). Ці слова видатного вченого підтверджують думку про те, що саме в науці в різних аспектах цілісності простежується міцний зв’язок «минулого-сучасного-майбутнього». Саме тому історико-педагогічні персонологічні дослідження сьогодні є одним із найпопулярніших напрямів наукових пошуків, в яких рефлексія минулого здійснюється через вивчення унікальної і неповторної історії життя і діяльності людини, яка, з одного боку, є творцем історії, з іншого, - іiї носієм. У цьому зв’язку, біографічний метод, як провідний інструмент вивчення творчої біографії особистості в історико-педагогічних розвідках, потребує згадування і детального розгляду.

Аналіз основних досліджень і публікацій. На сьогодні коло питань, досліджуваних вітчизняними істориками педагогіки досить широке і різноаспектне: це і зародження, становлення, розвиток педагогічної думки України; це і вивчення творчої спадщини відомих / не дуже відомих педагогів, учених, освітніх діячів та ії вплив на освітні реалії XXI століття; це і нові інтерпретації ідей і поглядів педагогічних персоналій минулого з урахуванням специфіки сьогодення; це і дослідження загальних концептуальних засад історикопедагогічної науки, їі понятійно-термінологічного апарату, розробка інноваційних методологічних стратегій історико-педагогічного дослідження; це і наукові розвідки з методології дослідження педагогічної персоналії тощо. У цьому контексті називаємо цілу плеяду відомих і знаних істориків педагогіки України - М. Антонця, Л. Березівську, М. Богуславського, Л. Ваховського, Н. Гупана, Н. Дічек, М. Євтуха, В. Майбороду, Н. Побірченко, Н. Сейко, М. Стельмаховича, О. Сухомлинську та ін.

Серед фундаментальних методологічних праць, присвячених проблемі дослідження біографічного методу, виділяємо: «Биография ученого как науковедческая проблема» (М. Ярошевський, 1974), «Биографический метод в психологии и смежных науках» (Н. Логінова, 1975), «Основания биографистики» 
(О. Валєвський, 1993), «Биографический метод» (В. Фукс-Хайнрітц, 1993), «Біографічна традиція та наукова біографія в історії і сучасності України (В. Чишко, 1996), «Биографический метод в исследованиях» (I. Дев'ятко, 1998), «Биография: силуэт на фоне Humanities (Методология анализа в социогуманитарном знании)» (I. Голубович, 2008), «Биографический метод в социальной педагогике и социальной работе» (Г. Соловйов, 2009), «Біографічний підхід в історико-філософському пізнанні» (В. Менжулін, 2010), «Биографика. Введение в науку и обозрение источников биографических сведений о деятелях России 18011917 годов» (I. Петровська, 2010), «Биографический метод в социологии» (О. Рождественська, 2012) та ін.

Мета статті полягає в аналітичному осмисленні біографічного методу як провідного інструменту вивчення творчої біографії особистості в історії педагогіки; у дослідженні його специфіки та характеристиці сукупності наукових принципів пізнання, які забезпечують ефективну реалізацію методу.

Виклад основного матеріалу дослідження. У науковий обіг термін «біографічний метод» було уведено у XIX ст. французьким поетом і критиком Ш. Сент-Бевом, який вивчення особистості у контексті її життєвого шляху пропонував здійснювати через упорядковане дослідження її внутрішнього світу, аналіз побутових і соціальних обставин, родинні зв'язки, властивості психіки, особливості душевного стану. У перекладі з грецької біографія - це життєпис (bios - «життя» и grapho - «пишу»). В одному із тлумачних словників біографія розуміється як опис найбільш значущих фактів життя і діяльності будь-якої людини в хронологічному порядку (Кузнецов, 2000, с. 57). Щодо власне появи і витоків цього феномену красномовними стануть слова дослідника біографістики С. Лі, який зазначав: «Біографія виникла на початку людства, для того, щоб задовольнити найдавніший інстинкт - меморіальний. Люди прагнуть передати нащадкам пам'ять про тих, хто характером і справами виділявся із загальної маси, хто захопив увагу сучасників і здатен також викликати зацікавленість майбутніх поколінь» (Lee, 1918, c. 10).

Зважаючи на етимологію поняття «біографія», задача біографа - максимально повно і точно описати, зафіксувати найбільш знакові факти життя і діяльності персоналії з метою розкриття ії̈ внутрішнього світу і відтворення картини суспільного життя тієї епохи, в якій вона жила і діяла. Проте в історичних розвідках виокремлюють ще один підхід до вивчення біографії - пояснення. Дослідження, виконане в руслі цієї парадигми зорієнтоване на виявлення логіки фактів і подій, встановлення причинно-наслідкових зв'язків, об’єднання всіх фрагментів життя персоналії в єдиний ланцюг «історії життя людини». 3-поміж сутнісних ознак біографічного пояснення історик О. Валевський виділяє: 1) дослідник має справу з подіями, які вже здійснилися, де дії об'єктивних причин і суб'єктивних мотивів для самого персонажа в момент вчинення дії були злиті воєдино; 2) поведінка індивідуальної людини більш індетермінована, ніж поведінка соціальної групи, класу, покоління; 3) біографічне пояснення неповторно, оскільки його неможливо виконати на основі регламентованих методичних рекомендацій і обов'язкових умов, яким має слідувати бідь-який біограф (Валевский, 1993, с. 39).

Як науковий метод осягнення індивідуальності, біографічний метод набуває сьогодні все більшої популярності, поширюючи дослідницький потенціал на всю систему гуманітарного знання - філософію, історію, соціологію, психологію, історію педагогіки та ін. науки. В структурі філософії теоретичні основи біографії розроблено німецьким істориком культури В. Дільтеєм, який убачав основною задачею біографа «побачити людину sub specie aeterni так само, як він сам відчуває себе в моменти, коли все навколо стає для нього покровом, шатами і посередником божества і він відчуває, що близький до неба, немов до якоїнебудь частці землі» (Дильтей, 1987, с. 134-135). В руслі філософського усвідомлення ролі біографічного методу цікавою видається типологія філософських біографій, запропонована Е. Соловйовим: а) життя мислителя як лабораторія думки, як процес становлення і розвитку ідей; б) подвижництво мислителя і його боротьба за суспільне визнання нової світоглядної концепції; в) життя мислителя як першого соціально значущого впровадження його ідеї; г) життя як здійснення мислителем особистісного синтезу різних форм духовної діяльності (Соловьев, 1991, с. 124).

В структурі історичного знання місце і роль біографії людини також стала предметом широкого обговорення науковців. Історик О. Клібанов підкреслює, що основним питанням історичної біографії є усвідомлення того, як історія відбивається в конкретній постаті і як ця постать відбивається в історії. Вчена Н. Пірумова задачу біографа убачає в об’єктивній реконструкції життя і діяльності персоналії на основі домінування пояснення над суб’єктивною оцінкою (Соловйов, 2018, с. 66). Як важливий напрям історичної науки сьогодні активно розвивається «персональна історія», фокусом дослідження якої стає історія життя людини, з її унікальністю, неповторністю, самобутністю. В типології історичних біографій дослідник Л. Репіна викоремлює такі її типи: а) «модальна біографія»- застосування біографії в якості статистичних даних в рамках соціологічних досліджень чи соціальної антропології; б) «контекстуальна біографія», де головним аспектом дослідження стає атмосфера та історичні реалії конкретної епохи, в якій жила і діяла персоналія; в) третій тип біографії характеризує життя персоналії на межі норм або порушень поширених форм поведінки; г) «герменевтична біографія», яка зорієнтовує дослідника на розуміння життя людини, особливостей її характеру, душевного і психічного стану, мотивів поведінки, намірів тощо (Репина, 1999, с. 7-13). 
В ареалі психологічної науки біографічний метод займає своє окремішнє місце, надаючи можливість дослідникові не лише вивчити людину в ії цілісності і розвитку, але й розкрити таємниці ї̈ внутрішнього світу, дослідити всі нюанси руху душі. Психолог Б. Ананьєв сутність біографічного методу розкриває через усвідомлення його як способу збирання та аналізу даних про життєвий шлях людини (як особистості, так і як суб'єкта діяльності). Учений запропонував цікаві дослідницькі стратегії вивчення людини - онтогенетику (вивчення онтогенезу, еволюції індивіда) і генетичну персоналістику (дослідження життєвого шляху людини) (Ананьев, 1980). Важливі біографічні дослідження в галузі психології свого часу проводили М. Рибніков, М. Рубінштейн, І. Соловьйов та ін.

Свою особливість біографічний метод має і в соціології, фокусуючи увагу на вимірі та оцінці історії життя людини, пов'язаного із ії безпосереднім соціальним оточенням і середовищем з позицій тих, хто це життя прожив. Важливим моментом для біографа в цьому контексті стає вивчення уявлення людини про своє життя та іiї місце в соціальній реальності; дослідження суб'єктивного ставлення людини до соціуму, який формує ії свідомість, погляди, переконання; з'ясування механізмів, подій і фактів, які спричинили становлення і розвиток особистості, та забезпечили подальше формування людської долі. Уперше наукове обгрунтування біографічного методу було здійснено представниками Чиказької соціологічної школи У. Томасом та Ф. Знанецьким. Учені пропонували розглядати соціальні процеси на підставі взаємодії розуму людини і її середовища, уважали, що, дослідження траєкторії життєвого шляху особистості допоможе узагальнити різні соціальні групи.

Розглядаючи роль біографічного методу в історико-педагогічній науці, звертаємося до фундаментальних теоретико-методологічних засад української історії педагогіки, обгрунтованих О. Сухомлинською. На тлі відсутності єдиного підходу до визначення предметного поля історії педагогіки, вчена виділяє, як окремий її предмет, творчу біографію педагога («персоналії»). За твердженням О. Сухомлинської, «звернення до творчої біографії $є$ і традицією, й інновацією, бо збагачує й урізноманітнює наші уявлення про історикопедагогічний процес, сприяє його новому прочитанню, а також відкриває нові грані, новий зміст, нові цінності цього процесу як важливі складові науковго дискурсу» (Сухомлинська, 2003, с. 37).

У цьому світлі сформувалася відповідна модель реконструкції національної педагогічної думки, яка включає: 1) опис життєдіяльності педагога; 2) власний особистісний підхід до розгляду педагогічного процесу (моральний, етичний зміст творчості); 3) предметний підхід (включеність або не включеність у тогочасний педагогічній процес); 4) ідейно-соціальні, культурницькі засади (розмаїття зв'язків з епохою, міра й сила їх впливів на педагогічні погляди) (Сухомлинська, 2003, с. 43). Важливим інструментом дослідження в цій моделі стає біографічний метод, визначений в історії педагогіки, як «спосіб опрацювання, аналізу джерел, за якого біографія, особистість педагога виступає, з одного боку, визначальним фактором його творчості, а з іншого - віддзеркалює епоху або ж $є$ їі творцем» (Сухомлинська, 2003, с. 44). Погоджуємося із наведеним визначенням і підкреслюємо, що, біографічний метод, як інструмент цілісного дослідження педагогічної персоналії, дозволяє через синтез «індивідуально-неповторного» і «загальносуспільного», через єдність «особистого» і «публічного» представити наукову біографію в її багатоаспектності і контекстності як «об'ємну» реконструкцію педагогічної персоналії; максимально об'єктивно і точно дослідити погляди, переконання, ідеї педагога, які є рушійними силами загального процесу розвитку педагогіки.

Ефективна реалізація дослідницького потенціалу біографічного методу в історико-педагогічних розвідках можлива за умов застосування сукупності наукових принципів пізнання. Зупинимося на цьому докладніше. Однією із найважливіших вимог до історико-педагогічного дослідження i, зокрема, персонологічних розвідок $\epsilon$ дотримання фундаментального принципу історизму, який $є$ одним із основних і визначальних у побудові методології науки. Особлива його роль в історико-біографічних розвідках полягає в тому, що, на тлі усвідомлення дослідником унікальності кожної епохи і динаміки розвитку будь-якого явища, принцип історизму забезпечує можливість: а) встановлення причин, обставин, витоків, чинників, передумов, які формували світогляд і педагогічне кредо діяча, визначали його професійну діяльність і спонукали до певних учинків, упливали на розвиток світосприйняття і професіогенезу; б) виявлення етапів розвитку педагогічних ідей i діяльності особистості у певній динаміці та часовій послідовності, обгрунтування еволюції і трансформування ідей, поглядів, переконань; в) здійснення наукової оцінки творчого внеску педагога, встановлення значення і наслідків його впливу на сферу діяльності; г) виокремлення прогностичних тенденцій подальшого розвитку ідей, теорій, концепцій; д) розкриття шляхів актуалізації педагогічної спадщини, окреслення напрямів використання прогресивного досвіду в контексті сучасних освітніх реалій тощо.

Варто зазначити, що інколи трапляються порушення принципу історизму, в результаті прагнення дослідника занадто «актуалізувати» спадщину того чи іншого педагога, «подати історію як пряме підтвердження чи аргумент сьогоднішньої теорії та практики» (Сухомлинська, 2003, с. 40). Через що проводяться неправомірні паралелі між минулим і сьогоденням, ігнорується історичний зміст і враховується лише зовнішня схожість термінів, понять, висловлювань педагогів минулого при поясненні освітніх реалій сьогодення, здійснюється підміна одних понять і фактів іншими, відбувається приписування педагогам неіснуючих ідей та поглядів. В результаті дослідження втрачає свою науковість і цінність. 
Із принципом історизму міцно пов'язаний загальнонауковий принцип системності, додержання якого в історико-біографічних розвідках $є$ обов'язковим. Використання принципу передбачає розгляд будь-якого історико-педагогічного явища чи факту у їх співвіднесенні, встановленні між ними взаємозв'язків і залежностей. В руслі цієї логіки, застосування принципу системності передбачає: а) розгляд педагогічних систем минулого в системі конкретних суспільно-політичних та ідеологічних відносин; б) дослідження історикопедагогічних фактів і явищ в контексті існуючих на той час освітніх систем і традицій; в) надання пріоритету аналізу і поясненню над формальним описом; г) вивчення ідей, поглядів, переконань педагогічних персоналій в межах їх цілісних освітніх концепцій, теорій, парадигм. Недотримання принципу системності створює загрозу ізольованості і «відірваності» дослідження від реальної історії.

В єдності із попередніми принципами розглядаємо принцип наукової об'єктивності, який вимагає сприйняття історико-педагогічних явищ і фактів в їх істинному існуванні і справжньому змісті, в їх розмаїтті і суперечливості, в єдності негативного і позитивного. У зв'язку із цим, застосування принципу об'єктивності до історико-педагогічних біографічних розвідок, насамперед, дає можливість: а) виявити в кожній епосі як прогресивне, перспективне, так і регресивне, консервативне, рутинне; б) встановити об'єктивну картину життєдіяльності персоналії, виокремлюючи реальні і хибні дані; в) реально оцінити значення певних історичних, педагогічних подій для особи, що спонукали їі до перемог, відкриттів, успіхів, або, навпаки, - спричинили низку поразок, творчих невдач, криз; з'ясувати ставлення до них; г) проаналізувати досягнення і помилки педагога, схарактеризувати позитивні та негативні впливи на становлення і розвиток його світоглядних, педагогічних поглядів, переконань, ідей; д) виявити спільноту однодумців, прибічників й, водночас, встановити «опонентське коло» педагога із критикою його ідей, теорій, концепцій тощо.

Відмітимо, що в реалізації цього принципу в історико-педагогічних дослідженнях персоналій не завжди вдається досягти абсолютної об'єктивності. Це пов'язано, насамперед, із особою дослідника, його педагогічними поглядами, внутрішнім духовним світом, методологічною культурою, який здійснює трактування тих чи інших історико-педагогічних подій крізь призму власного досвіду і світосприйняття. Тож при реконструкції окремих аспектів життєдіяльності особи (духовний, психологічний, емоційний стан), як зазначає О. Сухомлинська, «біограф може вдаватися до інтуїтивного осягнення, домислу, дослідницьких гіпотез та оцінок» (Сухомлинська, 2003, с. 44). Порушення використання принципу об’єктивності призводить до фальсифікації дослідження і його неправдивості.

Принцип відсутності догматизму уважаємо наступним, який вартує належної уваги і згадування. Він знаходиться у прямому і тісному зв'язку із попередніми принципами і за своєю специфікою вимагає від дослідника критичності до абсолютних істин, прогресивності поглядів, домінування «істини над упевненістю» (А. Конт-Спонвіль). В історико-біографічних педагогічних розвідках використання принципу передбачає: а) об'єктивне дослідження процесуальної істини, рух від фактів, реальності до ідей; б) неприпустимість приписування особі догм-постулатів, створення непогрішних авторитетів, «сліпого» слідування їм; в) обов'язкове врахування особливостей досліджуваного простору і часу при сприйнятті, оцінці й усвідомленні історико-педагогічних реалій; г) опір на доказовість і логіку; д) прагнення усебічно і неупереджено дослідити процес, незалежно від інтелектуальних традиції дослідника, його смаків і уподобань, позитивного чи негативного ставлення до того або іншого історичного факту, явища, персоналії тощо. Недотримання цього принципу призводить до відкидання цінних ідей і беззаперечних надбань минулого.

Зосереджуючись на специфіці біографічного методу як способу аналізу джерел, важливою засадою, що забезпечує його ефективну реалізацію, уважаємо принцип опору на історичні джерела. Сутність принципу полягає в пошуку потрібної інформації про минуле із джерел історії, які виступають цінним і часто єдиним носієм інформації, адже дослідник позбавлений змоги бути безпосереднім учасником тих або інших історичних подій. В історико-біографічному дослідженні педагогічної персоналії цей підхід, насамперед, передбачає: а) пошук максимальної сукупності достовірних прямих і суміжних джерел, їх глибинний порівняльний аналіз, вивчення, систематизацію і класифікацію; б) використання наукової біографії як пізнавального і цінного джерела історії; в) застосування найширшої кількості біографічних джерел щоденників, автобіографій, мемуарів, приватних листів, спогадів, інтерв'ю тощо.

Варто зазначити, що на сьогодні не існує однозначного й уніфікованого підходу до пріоритетності використання тих або інших джерел дослідження біографії - первинних, які є початковим, оригінальним джерелом інформації і засвідчують явище, факт безпосереднім учасником, свідком історичних подій; чи вторинних, які $€$ матеріалом, отриманим із першоджерел, і несуть інтерпретаційний характер, які пов'язані із коментарями, аналізом і критикою. В. Фукс-Хайнрітц наполягає на важливості першочергового застосування першоджерел, зокрема усних оповідей про життя конкретної людини (Фукс-Хайнритц, 1993, с. 12); Н. Дензін, як пріоритетні джерела, розглядає вторинні, документальні - автобіографії, біографії, некрологи та ін. (Дензін, 1989, с.7), I. Дев'ятко акцентує увагу на важливості і цінності як первинних, так і вторинних джерел (Девятко, 1998, с. 48). 3-поміж первинних джерел науковець виділяє: усну чи письмову оповідь, інтерв’ю, опитування та ін.; зпоміж вторинних: мемуари, листи, офіційні документи, особисті листи, приватні записи, публічні та приватні 
архівні матеріали, щоденники, записи розмов, чернетки і нотатки праць, плани роботи та ін. Кожен дослідник обирає свій підхід залежно від предметного поля наукових пошуків, доступності джерел, їх кількості, способів використання і класифікації; важливо - уникати їх абсолютизації i, як справедливо, свого часу зазначав історик М. Блок, усвідомлювати, що джерелом для історика є все, що вказує на присутність людини в історичному процесі (Блок, 1970, с. 80). При роботі із джерельною базою, безперечно, не можна ігнорувати і методами аналізу джерел, зокрема методом вивчення різнопланових історико-педагогічних джерел, методом історіографічного аналізу, методом історичної критики біографічних масивів та ін.

Загалом питання джерельного забезпечення історико-педагогічних розвідок вартує окремої найсерйознішої уваги і найретельнішого вивчення, адже недооцінка джерельної бази, ії поверхневий і некоректний аналіз призводить до суб’єктивізації дослідження та його недостовірності.

Перелік принципів історико-науковго пізнання, безумовно, можна продовжувати. Принцип єдності, конкретності, всебічності, синтезу історичного та логічного, соціально-історичної детермінації педагогічної дійсності, історіографічної традиції та інші потребують належного згадування і уваги. Кожен із них є важливим у побудові методології дослідження в цілому і реалізації біографічного методу зокрема.

Підсумовуючи зазначене, узагальнимо особливості біографічного методу в історико-педагогічному дослідженні персоналії. Серед них виділяємо:

•наявність потужного дослідницького потенціалу та відповідного інструментарію для «одухотворення» історико-педагогічного процесу, доповнення його живим змістом, трансформування із абстрактного і формалізованого на діалогічний і персоніфікований;

•ключовий фокус уваги на глибині і таємниці внутрішнього світу людини, її унікальності і духовності, динаміці життя на тлі суспільних подій та історичної епохи, у певному просторі і часі («синтез індивідуально-неповторного і загальносуспільного», єдність «особистого» і «публічного»);

•спрямованість на реконструкцію фактів життя персоналії, історичної, розгорнутої в часі, перспективи подій, в якій педагог-дослідник мимоволі стає істориком;

•прагнення до максимально «об'ємної» реконструкції життєдіяльності педагога, до різнобічного і цілісного охоплення життя у множині факторів, що визначають його рух і направленість;

•суб’єктивність, можливість врахування дослідником особистих поглядів і переконань, власної інтелектуальної традиції при вивченні історії людського життя, висунення власних гіпотез, інтерпретацій, оцінок;

•здатність до розвитку, невичерпності, збагачення новими ідеями та принципами, прийомами і правилами залежно від нових засад і тенденцій розвитку гуманітарних наук в Україні та світі;

•опір на історичне джерело як важливий засіб забезпечення достовірності та повноти реалізації біографічного методу.

Висновки дослідження і перспективи подальших розвідок. На завершення хотілося б зазначити, що, незважаючи на зростання кількісного масиву історико-педагогічних біографічних розвідок, залишається важливою їх якість і прогресивність для науки, що може бути зреалізовано через: а) пріоритет вивчення генезису і трансформування феноменів науки, адекватний пошук у минулому витоків сучасних проблем; б) методологічно грамотне застосування біографічного методу з усією сукупністю його ідей і принципів, правил і прийомів; в) дотримання органічної єдності трьох проекцій - «ретроспективного осмислення минулого, об'єктивної оцінки сучасного, чіткого й усвідомленого прогнозування майбутнього»; г) розкриття істинного історико-педагогічного процесу з усіма його хибами і недоліками, з аналізом досягнень і помилок персоналій; д) володіння дослідником високою науковою кваліфікацією, педагогічним світоглядом, широкою ерудицією та етикою, досвідом критичного аналізу джерел, знанням закономірностей перебігу історико-педагогічного процесу тощо.

Перспективи наукових пошуків у майбутньому доцільно спрямувати як на подальшу розробку методологічних засад біографічного методу в історико-педагогічній науці, так і на пошук інноваційних методологічних стратегій історико-педагогічного дослідження.

\section{СПИСОК ВИКОРИСТАНОЇ ЛІТЕРАТУРИ}

Ананьев Б. Г. Избранные психологические труды : в 2-х т. Москва : Педагогика, 1980. Т. 1. 232 с.; Т. 2. 288 с. Блок Марк. Большая советская энциклопедия. Т. 3 / под ред. А. М. Прохорова. 3-е изд. Москва : Сов. энцикл., 1970. С. 424. Большой толковый словарь русского языка / под ред. С. А. Кузнецова. Санкт-Петербург : Норинт, 2000. С. 57. Валевский А. Л. Основания биографики. Киев : Наук. думка, 1993.110 с.

Вернадский В. И. Очерки и речи. Т. 2. Петербург : Научхимтехиздат, 1922. 123 с.

Девятко И. Ф. Методы социологического исследования. Екатеринбург, 1998. 208 с.

Дильтей В. Введение в науки о духе. Зарубежная эстетика и теория литературы XIX - XX вв / ред. Г. К. Косиков. Москва, 1987. С. $108-135$.

Менжулін В. І. Біографічний підхід в історико-філософському пізнанні : монографія. Київ, 2010. 455 с.

Репина Л. П. Персональная история: биография как средство исторического познания. Казус: индивидуальное и уникальное в истории. 1999. Т. 2. С. 7-13. 
Соловйов Г. Е. Качественная методология в социальной работе. Ижевск, 2018. 172 с.

Соловьев Э. Ю. Прошлое толкует нас. Москва : Политиздат,1991. 432 с.

Сухомлинська О. Історико-педагогічний процес: нові підходи до загальних проблем. Київ : А.П.Н., 2003. 68 с.

Фукс-Хайнритц В. Биографический метод. Биографический метод в социологии: история, методология, практика / ред. кол.: В. В. Семенова, Е. Ю. Мещеркина. Москва : Ин-т социологии РАН, 1993. С. 11-41.

Ярошевський М. Г. Биография ученого как науковедческая проблема. Человек науки. Москва : Наука, 1974. С. 19-57.

Denzin N. The Research Act: A Theoretical Introduction to Sociological Methods. New Jersey : Prentice Hall, 1989. 306 p.

Lee S. The Perspective of Biography. London : The English Association, 1918. P. 10.

\section{REFERENCES}

Anan'ev, B. G. (1980). Izbrannye psihologicheskie trudy [Selected Psychological Works] (Vol. 1/2). Moskva: Pedagogika [in Russian]. Blok Mark. (1970). Bolshaia sovetskaia entciklopediia [The Great Soviet Encyclopaedia] (Vol. 3). Moskva: Sov. entcikl. [in Russian]. Denzin, N. (1989). The Research Act: A Theoretical Introduction to Sociological Methods. New Jersey : Prentice Hall.

Deviatko, I. F. (1998). Metody sotciologicheskogo issledovaniia [Sociological research methods]. Ekaterinburg [in Russian].

Diltei, V. (1987). Vvedenie v nauki o dukhe [Introduction to the Spiritual Sciences]. In G. K. Kosikov (Ed.), Zarubezhnaia estetika i teoriia literatury XIX - XX vv. [Foreign aesthetics and literary theory of the 19th and 20th centuries] (pp.108-135). Moskva [in Russian].

Fuks-Khainrittc, V. Biograficheskii metod [The biographical method]. In V. V. Semenova, \& E. Iu. Meshcherkina (Eds.), Biograficheskii metod $v$ sotciologii: istoriia, metodologiia, praktika [The biographical method in sociology: history, methodology, practice] (pp. 11-41). Moskva: In-t sotciologii RAN [in Russian].

Iaroshevskii, M. G. (1974). Biografiia uchenogo kak naukovedcheskaia problema [The biography of a scientist as a research problem]. In Chelovek nauki [Man of science] (pp. 19-57). Moskva: Nauka [in Russian].

Kuznetcova, S. A. (Ed.). (2000). Bolshoi tolkovyi slovar russkogo iazyka [The Great Dictionary of the Russian Language]. Sankt-Peterburg: Norint [in Russian].

Lee, S. (1918). The Perspective of Biography. London : The English Association.

Menzhulin, V. I. (2010). Biohrafichnyi pidkhid v istoryko-filosofskomu piznanni [The biographical approach in historical and philosophical scholarship]. Kyiv [in Ukrainian].

Repina, L. P. (1999). Personal'naja istorija: biografija kak sredstvo istoricheskogo poznanija [Personal history: biography as a means of historical knowledge]. Kazus: individual'noe i unikal'noe v istorii [Casus: the individual and the unique in history], 2, 7-13 [in Russian].

Soloviov, G. E. (2018). Kachestvennaia metodologiia v sotcialnoi rabote [Qualitative methodology in social work]. Izhevsk [in Russian]. Sukhomlynska, O. (2003). Istoryko-pedahohichnyi protses: novi pidkhody do zahalnykh problem [The historical and pedagogical process: new approaches to common problems]. Kyiv: A.P.N. [in Ukrainian].

Valevskii, A. L. (1993). Osnovaniia biografiki [Background to the biography]. Kiev: Nauk. Dumka [in Russian].

Vernadskii, V. I. (1922). Ocherki i rechi [Essays and speeches]. (Vol. 2). Peterburg: Nauchkhimtekhizdat [in Russian].

\section{OLENA ILCHENKO}

\section{BIOGRAPHICAL METHOD IN HISTORICAL AND PEDAGOGICAL RESEARCH: ESSENCE, PRINCIPLE, SPECIFICITY}

The article examines the role and importance of the biographical method as a key tool for studying the creative biography of a person in the history of pedagogy. It is recognised that, as a scientific method of perceiving identity, the biographical method has been gaining more and more popularity, by extending the investigative potential to the whole system of humanitarian knowledge - philosophy, history, sociology, psychology, history of pedagogy and other sciences.

The article summarises the features of the biographical method in historical and pedagogical research, analyses the scientific principles of knowledge that ensure the effective implementation of the investigative potential of the biographical method (the principle of historicism, systematism, scientific objectivity, absence of dogmatism, reliance on historical sources).

The author noted that despite the growing number of historical and pedagogical biographies, their quality and progressiveness for science is still important, which is possible under the conditions of: a) priority of studying the genesis and transformation of scientific phenomena, adequately searching for the sources of contemporary problems in the past; b) methodologically sound application of the biographical method with the totality of its ideas and principles, rules and techniques; c) clear maintenance of the organic integrity of the three projections - "retrospective assessment of the past, an objective appraisal of the present, and a clear and informed foresight of the future"; d) revealing the true essence of the historical and pedagogical process with all its strengths and weaknesses, with an analysis of individual accomplishments and failures; e) the researcher having a high scientific qualification, pedagogical outlook, broad observation and ethics, experience in critical analysis of the literature, knowledge of the historical and pedagogical process, etc.

Key words: pedagogical personality; biographical method; biography; principles of recognition; specificity of the biographical method; historical and pedagogical research. 